\title{
A STUDY ON SPATIAL LEGIBILITY OF STREET NETWORK AROUND RAILWAY STATION
}

\author{
Yi KANG ${ }^{1}$, Kiyotaka FUKAHORI ${ }^{2}$, Yoichi KUBOTA ${ }^{3}$ \\ and G. M. W. L. GUNAWARDENA ${ }^{4}$ \\ ${ }^{1}$ Graduate student, Dept. of Environmental Science and Technology, Saitama University \\ (255, Shimo-ookubo, Sakura-ku, Saitama-shi, Saitama 338-8570, Japan) \\ E-mail: kou_ki1985@yahoo.co.jp \\ ${ }^{2}$ Associate Professor, Division of Environmental Science and Infrastructure Eng., Saitama University (Ditto) \\ E-mail: fukahori@post.saitama-u.ac.jp \\ ${ }^{3}$ Professor, Division of Environmental Science and Infrastructure Eng., Saitama University (Ditto) \\ E-mail: ylkubota@env.gse.saitama-u.ac.jp \\ ${ }^{4}$ Graduate student, Dept. of Environmental Science and Technology, Saitama University (Ditto) \\ E-mail:w.lakpriya@gmail.com
}

\begin{abstract}
This study was conducted to verify the effects of some geometric factors, such as the angular direction change, the available visual information amount, the width variation of streets, and the axis deviation on street space on the continuity of the street network, to have a good legibility along the street. The main purpose of this research is to provide a classification of route types considering the legibility of street space. The experiment was conducted around the Minami Urawa Station in Saitama Prefecture. The street network in the study area was analyzed using two types of parameters, such as visibility parameters and spatial parameters. The visibility parameters were obtained through statistical calculations using visibility attributes defined through a field survey, while spatial parameters were hypothetically defined using the knowledge about the street network of the study area and referring to the literature. Both parameters were analyzed using PCA (Principal Component Analysis) and Cluster analysis to define route types.

The results of the research clearly illustrated that there was a significant relationship between the visual characteristics of the street network and the street space legibility. Seven types of routes were classified and their attributes were clarified. These attributes affected the wayfinding behavior of the pedestrians in the study area.
\end{abstract}

Key Words: wayfinding behavior, visual information, street forms, street space legibility

\section{INTRODUCTION}

\section{(1) Wayfinding behavior}

Cities are like living organisms. They are incessantly changing vertically and horizontally with time. However, the legibility of the cities should be maintained in a constant manner for the benefit of the city dwellers and the other visitors.

When the cityscape becomes complex, finding one's way in the streets becomes a tedious task. Wayfinding in a complex setting with little survey knowledge about the city requires decision making under uncertainty. Often, wayfinding involves using the directions provided by maps or persons familiar with the area. Further, the legibility of the traveling area is important for finding the correct path to move from one place to another. Some people are innately skilled in finding their way in any unknown surrounding although the place is legible or not, while others lack this ability. This ability is called "sense of direction." According to Kozlowski and Bryant ${ }^{1)}$, sense of direction is a consciousness of location or orientation. Further, Sholl et al. ${ }^{2)}$ emphasized that sense of direction is knowledge of the location and orientation of the body with respect to the large stationary objects, or landmarks, attached to the surface of the earth.

According to Golledge ${ }^{3)}$, "wayfinding is a cognitive psychological process for finding a pathway from an origin to a specified destination. It is a complex process and will be different for individuals depending on the purpose of the trip or in response to external environmental conditions. Zhou and Golledge ${ }^{4)}$ stated that, wayfinding is composed of 
two components: movement and decision making. The important attributes of movement in wayfinding include: a route of motion (points and lines), the velocity of motion (direction and speed), time parameters related to the movement (arrival or departure time, duration of stay) and the mode of movement or motion (for example, by walking or via mechanized transport such as car or bus). According to Weisman ${ }^{5)}$, three major environmental factors affect the orientation and wayfinding behavior of humans; these are, differentiation, visual access, and layout complexity. Environments differ with respect to shape, color, size, architectural style, etc. More differentiated environments have enough landmarks to memorize during traveling. Visual access is the amount of visual information gathered from the environment while traveling. The greater the visibility, the greater the ease of access to the destination. More complex layouts basically make wayfinding a difficult chore. If a space is busted into more different parts, the space becomes complex, and in such complex environments, wayfinding becomes tedious. Golledge ${ }^{3)}$ discussed the decision making in the human wayfinding process. He stated that decision making during wayfinding is a process of deciding which path to traverse when faced with a series of alternatives. In resolving which path to take, decisions can be made according to criteria including shortest path, least time taken, fewest turns or most scenic path. Further, he suggested that the decision maker may not be completely conscious of using specific wayfinding strategies or criteria.

Nevertheless, people follow certain rules during the wayfinding process based on the spatial relationships between objects. Referred to as topology, these spatial relationships between objects include proximity, separation, order, and enclosure. On top of topological knowledge, tourists will use their inherit knowledge and habits from previous movements to wayfind $^{6}$. Besides, people may or may not choose to use landmarks, and these landmarks will vary depending upon the environment that is being navigated. Different people may also use different landmarks in the same environment ${ }^{7)}$. Sorrows and Hirtlee $^{8)}$ delved into the importance of landmarks in wayfinding behavior. They stated that a landmark was a salient object used as a reference to help people memorize and recognize routes and locate themselves in terms of their ultimate decision. Landmarks can be natural, like a rock outcrop or a large tree stand; or artificial, for example a building or street corner $^{3)}$. One characteristic of landmarks is singularity, or salience, which refers to their distinct qualities in contrast to their background ${ }^{9), 10), 11)}$. Passini ${ }^{12)}$ confirmed that landmark recognition is a dominant process in wayfinding. Subjects in his experiment had poor spatial knowledge of a shopping mall in their route- and configuration-like sketch maps, but were still able to successfully find their way in the mall. Passini ${ }^{12)}$ concluded that the participants were able to recognize landmarks in the context of navigation even if they were not able to recall them when drawing sketch maps. Baskaya et al. ${ }^{13)}$ conducted an investigation similar to that of Passini ${ }^{12)}$. They explored the wayfinding behavior of newcomers in an unfamiliar environment. They performed the experiment similar to that of Passini ${ }^{12}$ ) in a complex building and brought into being that subjects were able to find their way with the help of the landmarks in the building. Accordingly, landmarks play an important role in wayfinding behavior. Still, there are other factors that affect wayfinding using landmarks, such as level of familiarity with environment, visual access, plan configuration, and individual differences ${ }^{5), 8), 9), 14) . ~}$

\section{(2) Research scope and related studies}

This paper studied the relationship between the legibility of a street space and the wayfinding process of the pedestrians. As Weisman ${ }^{5)}$ expressed, differentiation, visual access, and layout complexity impinged on the wayfinding behavior of humans. The layout complexity and legibility of an environment are allied to each other; when the environment is more complex, by and large the legibility of that environment becomes stumpy and vice versa. In other words, the physical characteristics of the environment influence the wayfinding behavior; they can make it easier or harder to acquire spatial knowledge and to perform various navigation tasks ${ }^{15)}$. Lynch $^{9)}$ explained this effect using the term environmental legibility. He elucidated that environmental legibility was "the ease with which its parts can be recognized and can be organized into coherent pattern." Visual complexity was the quality of the plan configuration, namely, the spatial relations between the objects of the environment. It was found that wayfinding was easier when the plan configuration of the urban environment was close to "good form" or to "good gestalt," which is a configuration characterized by simplicity, symmetry, regularity, and continuity ${ }^{5), 16)}$.

In this experimental study, legibility of the street space was scrutinized using four factors: the angular direction change, the available visual information amount, the width variation of the routes, and the axis deviation. Previous studies explored the effect of visual access or available visual information amount on the legibility of an environment. Shokouhi ${ }^{17)}$ stated that a high degree of global integration (shorter topological depth of a given unit compared to all other visual units) contributes to the immutability of urban objects or street segments. Kuipers ${ }^{18)}$ researched the use of the visual senses in navigation, while Turner and Penn ${ }^{19)}$ brought into being the relationship be- 
tween visual field and human behavior in wayfinding process.

Nonetheless, there were no sufficient studies on the other factors that clearly affected the legibility of an environment and the wayfinding behavior as stated above. Albeit some past researches studied the effect of available visual information on the legibility of street space, the data collection was narrowed to either the origin or the destination points of the street network. In this study, the whole street network was considered and data were collected from each intersection of the routes to address above drawbacks in the previous studies. In consequence, the specific aim of this study is to examine the effects of the following on street space legibility and wayfinding behavior:

- the angular direction change between the route and the linear axis drawn from each intersection of the route to the destination

- the available visual information on the route

- the route width variation, and

- the route direction deviation from the linear axis of route.

The research has two main hypotheses:

1. A sufficient amount of visual information is accessible to the pedestrian throughout the route attesting that each route has a high legibility with respect to the factor, "the available visual information amount of the route." The visible range is considered up to the walls of the buildings on either side of the route. Pedestrians habitually look around the route while traveling; hence, the field of view of pedestrians was considered as $360^{\circ}$.

2. The route direction deviation from the linear axis of the route has an effect on the legibility of the route. If the deviation between route and linear axis is larger, subsequently the legibility of the route becomes lower.

To examine these hypotheses, the experimental study was performed in the streets close to a railway station in Saitama Prefecture in Japan. Street network and the surroundings affect one's understanding of places in the city. With the help of a topographical map, it is possible to obtain cues for survey knowledge about the place; however, the question arises: How do pedestrians identify the place indicated by map information by observing the visibility of surrounding landscape? As a fundamental condition, visibility of the urban landscape, which is caused by sufficient amount of open space within street network, is an important contributing factor to spatial orientation in the landscape. Consequently, by examining these hypotheses, this study attempted to analyze both the legibility of the street network and the identifiability of urban landscape.

\section{METHOD}

\section{(1) The study area}

The study area was within a circle of radius 400$500 \mathrm{~m}$ around the entrance point of Minami Urawa Station in Saitama City.

The surroundings of the Minami Urawa Station were divided into four areas by two main railway lines: Kehintoku Line and Musashino Line. Along Kehintoku Line the neighborhood streets comprise basically a network structure; however, along $\mathrm{Mu}-$ sashino Line the neighborhood streets exhibit an irregular pattern (Fig. 1).

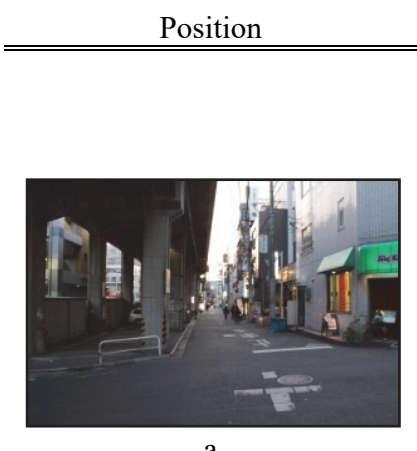

a

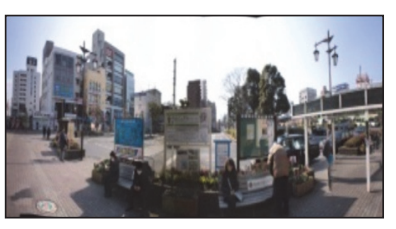

c

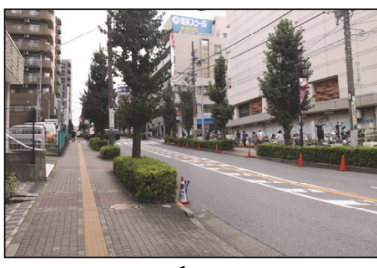

b

(a) Musashino Line is an overhead railway. This line looks like a high wall that disrupts the visibility of the other side of the district and it gives an oppressive feeling to the pedestrian. However, the linear railway is an effective cue for spatial orientation including the direction of street network and major landmarks such as railway station.

(b) This street is connected to the square of the railway station and the station building is a major landmark of the street. The street has sufficient open space and the straight street is very visible even from a far distance from the station.

(c) The west side of Minami Urawa Station has a wide open space with a square and pedestrian path. Various streets are connected to the station square and route information is adequate. While the street and the square are connected and are highly visible, the route length within the square edge is short. Thus, pedestrians may have to take several turns and the direction to the destination may change.

Fig. 1 The study area (these three photographs are described in Fig. 8). 


\section{(2) Method}

The analysis of the legibility was carried out using several analytical procedures. All these analytical methods tied together to give the final outcome of the research. The steps are summarized as follows:

- A preliminary field survey was performed to collect physical information about the station and the surrounding area. The collected physical information were the route length, the route width, the angle between the route direction and the linear axis, the field of view, etc.

- Anchored on the collected data were some hypothetical parameters, such as the average path width, each linear axis change, the average rotation angle, etc. were established for the routes around the station.

- Using Principal Component Analysis (PCA), these hypothetical parameters of the routes were analyzed and consolidated and mutually independent component parameters were obtained.

- Cluster analysis was executed using obtained components to classify the routes in the study area.

- To know the degree of legibility of all route types, perceived legibility scales were measured onsite. It was done for 56 streets in the study area with the help of 51 subjects. The legibility parameters were: cognitive gaps in identifying the direction of the destination, recall rate of the memorized route scene, difficulty of route choice in the intersections, possibility of choosing a false street at intersections, and the recognition rate of route choice in the map.

- The mean of quantified legibility scales for all route types were analyzed to grasp the feature of each route type on multiple legibility aspects.

- The multiple regression models were obtained to estimate the degree of perceived legibility by four principal components of route configuration and physical route parameters.

Some parts of the analysis process referred to Taguchi and $\mathrm{Wada}^{20)}$. Taguchi quantified physical route configuration parameters, variance of street width, direction of route segment, etc. Some parameters were aggregated data of each route segment for the whole route but most of the parameters only focused on the end of route segments. By applying PCA on some districts including the shortest routes, four components were derived. In contrast, our study added new parameters, specifically average visible area from a route, and variance of linear axis from route origin to destination. In addition, all of our physical route configuration parameters were defined as aggregated parameters in the whole route. Wada obtained 15 types of routes using Taguchi's route parameters and clarified the features of district charac- terized by routes. On the other hand, our study also aimed to obtain different kinds of route types based on the visibility consideration, and the most distinguished contribution of this study was to clarify the legibility of route types and to create a model to estimate the legibility score of the route by using principal components of the physical route configuration parameters.

\section{(3) Physical route parameters and consolidation of parameters by principal component analysis}

For the legibility evaluation of the route, physical route parameters were defined. These parameters designated spatial configuration of the street network and focused on the geometric relations of street linkage. Based on the preliminary field visit and the previous studies on geometric features of street network, the following parameters were derived for the quantitative analysis of the street space:

- The average path width in a route

- The average angle between route segments and the linear axis drawn from each route intersection to the destination of the route

- The average change in the linear axis angles drawn from each route intersection to the destination of the route.

- The average rotation angle of a route

- Changes in the width of a route

- The area between route and the linear axis of route

- The average available visual information amount of a route (Fig. 2).

The available visual information amount is the total amount of the view shed (visible area from a particular position) measured at multiple viewpoints in the route. In this study, it was assumed that higher legibility could be obtained in higher visual information amount. If sufficient visibility of street elements was given, the pedestrian was likely to obtain effective information for wayfinding.

Although it was possible to define multiple viewpoints within one section, the viewpoints were defined only at the intersection or the turning point. In this study, the effects of visibility on legibility were concentrated at the intersection because the intersection was where the walker felt uneasy if he well understood the place and route at the time of route choice. Thus, the viewpoints were defined only at each intersection or turning point of the route to count the available visual information amount.

In Fig. 2, position1 7are the defined viewpoints and visible area from each point is measured and overlaid. The overlapping area is not double counted.

In order to compare routes with different lengths, this amount is divided by the number of intersections in the route. The area size of visible area from the 
Table 1 Definitions of basic physical attributes.

\begin{tabular}{|c|c|}
\hline Physical Attribute & Notation \\
\hline The rotation angle & $\mathrm{H}$ in degree $(\mathrm{H} 1 . \mathrm{H} 2 . \mathrm{H} 3 \ldots)$ \\
\hline $\begin{array}{l}\text { The route length from the origin to } \\
\text { the destination }\end{array}$ & $\mathrm{S}$ in meters \\
\hline The number of intersections passed & $\mathrm{D}$ \\
\hline Route segments & $\mathrm{K}$ in degree $(\mathrm{K} 1 . \mathrm{K} 2 . \mathrm{K} 3 \ldots)$ \\
\hline Angular change in the linear axis & $\mathrm{JH}$ in degree $(\mathrm{JH} 1 . \mathrm{JH} 2 . \mathrm{JH} 3 \ldots)$ \\
\hline $\begin{array}{l}\text { The angle between linear axis and } \\
\text { the route direction }\end{array}$ & $\mathrm{JK}$ in degree $(\mathrm{JK} 1 . \mathrm{JK} 2 . \mathrm{JK} 3 \ldots .)$. \\
\hline Route width increase & $\mathrm{HH}$ in meters \\
\hline Route width & $\mathrm{W}$ in meters (K1W. K2W. K3W....) \\
\hline Route segment length & L in meters (K1L. K2L. K3L....) \\
\hline Route width decrease & HS in meters \\
\hline $\begin{array}{l}\text { The area size between route and the } \\
\text { linear axis for each route segment }\end{array}$ & $\mathrm{M}$ in square meter (M1. M2. M3.....) \\
\hline Method of HH calculation & $\begin{array}{l}\text { if }(\mathrm{K} 2 \mathrm{~W}-\mathrm{K} 1 \mathrm{~W}),(\mathrm{K} 3 \mathrm{~W}-\mathrm{K} 2 \mathrm{~W}) \ldots \leq 0 \text { then it was considered as } 0 . \\
\text { If } \operatorname{not}(\mathrm{K} 2 \mathrm{~W}-\mathrm{K} 1 \mathrm{~W}) / \mathrm{K} 1 \mathrm{~W}+(\mathrm{K} 3 \mathrm{~W}-\mathrm{K} 2 \mathrm{~W}) / \mathrm{K} 2 \mathrm{~W}+\ldots\end{array}$ \\
\hline Method of HS calculation & $\begin{array}{l}\text { if }(\mathrm{K} 1 \mathrm{~W}-\mathrm{K} 2 \mathrm{~W}),(\mathrm{K} 2 \mathrm{~W}-\mathrm{K} 3 \mathrm{~W}) \ldots \leq 0 \text { then it was considered as } 0 . \\
\text { If } \operatorname{not}(\mathrm{K} 1 \mathrm{~W}-\mathrm{K} 2 \mathrm{~W}) / \mathrm{K} 1 \mathrm{~W}+(\mathrm{K} 2 \mathrm{~W}-\mathrm{K} 3 \mathrm{~W}) / \mathrm{K} 2 \mathrm{~W}+\ldots\end{array}$ \\
\hline
\end{tabular}

Table 2 Description of each physical parameter.

\begin{tabular}{|c|c|c|}
\hline Physical Parameter & Statistical Expression & Description \\
\hline $\begin{array}{l}\text { The average rotation angle in } \\
\text { a route }\end{array}$ & $(\mathrm{H} 1+\mathrm{H} 2+\ldots) / \mathrm{D}$ & $\begin{array}{l}\text { Total of rotation angles in the route intersections/ The total } \\
\text { number of intersections. }\end{array}$ \\
\hline $\begin{array}{l}\text { The average path width in a } \\
\text { route }\end{array}$ & $\begin{array}{l}(\mathrm{K} 1 \mathrm{~W} * \mathrm{~K} 1 \mathrm{~L}+\mathrm{K} 2 \mathrm{~W} \\
* \mathrm{~K} 2 \mathrm{~L}+\ldots) / \mathrm{KS}\end{array}$ & $\begin{array}{l}\text { The average of the route width was considered as a sum of } \\
\text { the widths from the origin to the destination of the route. } \\
\mathrm{KS} \text { is the length of the route } \mathrm{K} . \mathrm{KS} \text { in meters. }\end{array}$ \\
\hline $\begin{array}{l}\text { The average change in the } \\
\text { linear axis angles drawn } \\
\text { from each route intersection } \\
\text { to the destination of the } \\
\text { route. }\end{array}$ & $(\mathrm{JH} 1+\mathrm{JH} 2+\ldots) / \mathrm{D}$ & $\begin{array}{l}\text { From the origin to the destination, the linear axis angle } \\
\text { changes in each intersection. To obtain this index, total of } \\
\text { these changed angles were divided by the total number of in- } \\
\text { tersections. }\end{array}$ \\
\hline $\begin{array}{l}\text { The average angle between } \\
\text { route segments and the linear } \\
\text { axis drawn from each route } \\
\text { intersection to the destina- } \\
\text { tion of the route }\end{array}$ & $(\mathrm{JK} 1+\mathrm{JK} 2+\ldots) / \mathrm{D}$ & $\begin{array}{l}\text { The summation of total angle between linear axis and the } \\
\text { route direction is divided by the number of intersections in } \\
\text { the route. It is hypothesized that the smaller this angle, the } \\
\text { probability to select this route becomes higher. }\end{array}$ \\
\hline Changes in width of a route & HH-HS & The route width differences between route segments. \\
\hline $\begin{array}{l}\text { The average area between } \\
\text { route and the linear axis }\end{array}$ & $(\mathrm{M} 1+\mathrm{M} 2 \ldots) / \mathrm{S}$ & $\begin{array}{l}\text { Total area between the traveling route and the linear axis. The } \\
\text { area between two lines depend on the change in the angle be- } \\
\text { tween two lines }\end{array}$ \\
\hline $\begin{array}{l}\text { The average available visual } \\
\text { information amount of a } \\
\text { route }\end{array}$ & (Fig. 2) & $\begin{array}{l}\text { The visible range was measured up to the walls of the build- } \\
\text { ings on either side of the route. Pedestrians habitually look } \\
\text { around the route while traveling; hence, the field of view of } \\
\text { pedestrians was considered as } 360^{\circ} \text {.( unit sqm) }\end{array}$ \\
\hline
\end{tabular}




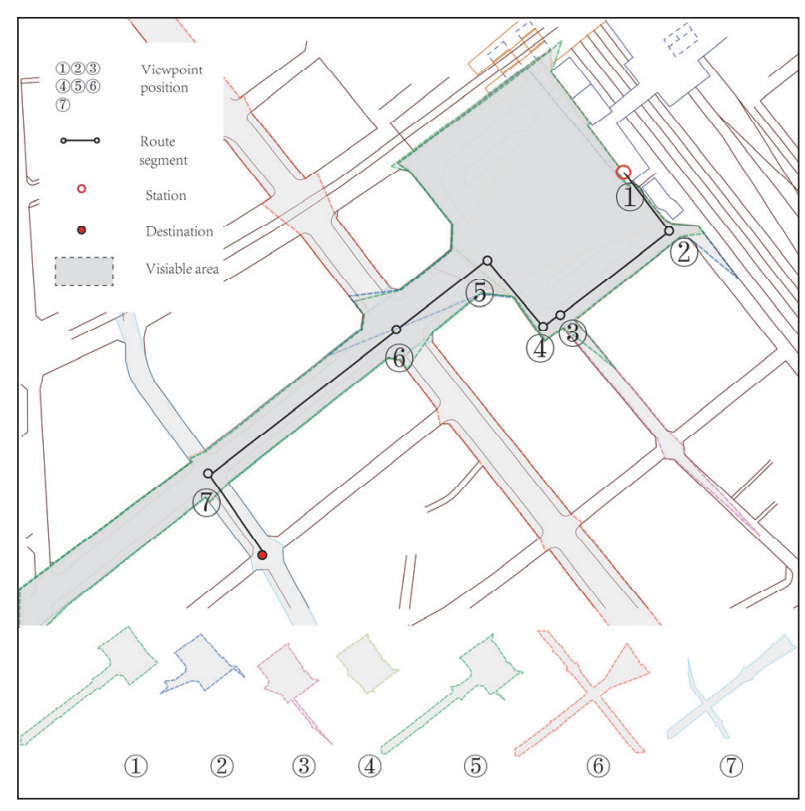

Fig. 2 The available visual information amount.

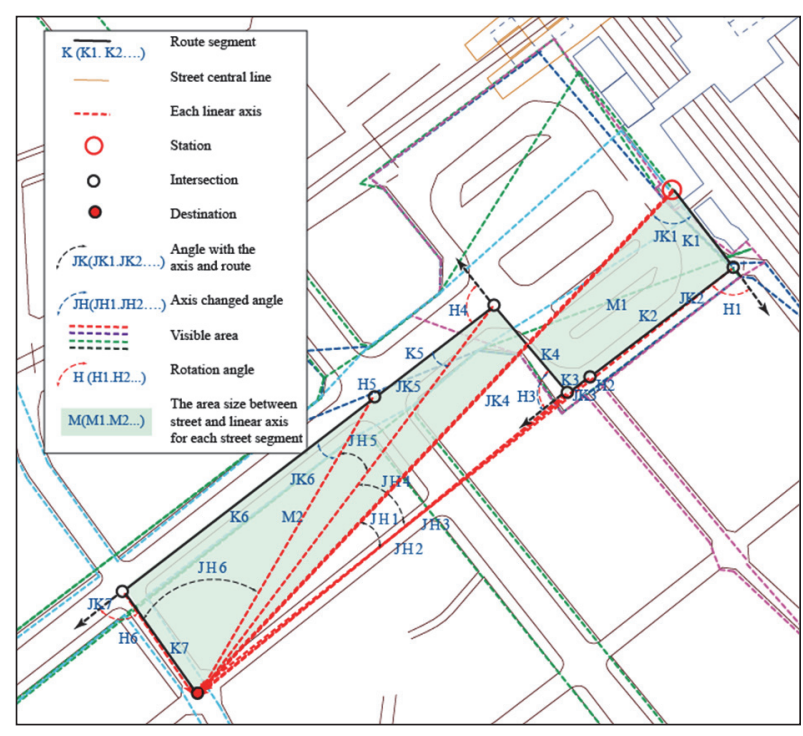

Fig. 3 Street Space Parameters.

viewpoint is counted considering the position of the building wall line alongside the route. Maximum limit of the visibility length is $500 \mathrm{~m}$ from the viewpoint (Fig. 2).

Above parameters were derived using the physical attributes that were identified and measured on the routes during preliminary field surveys. Table 1 puts in plain words the above physical attributes while Table 2 explains the derived physical parameters (Fig. 3).

\section{(4) Classification of the routes by cluster analysis}

The cluster analysis was performed using the four components derived through PCA analysis. As the four principal components obtained by PCA, the attributes of various routes regarding geometric configuration of the network can be assessed. If the effect of these components on the legibility is demonstrated, then it might be possible to estimate the degree of legibility in the total street network. In addition, to propose improvements on the legibility of route in practical design stage, it is effective to provide a classification of route types into legible geometric configuration.

\section{(5) Evaluation of the routes legibility by on-site psychological experiment}

Six psychological indicators (Table 6) were measured in the field survey with 51 subjects (males, 27; females, 24). The experiment was conducted from March to June in 2014. Respondents walked about four hours in daytime to answer the perceived legibility of the selected 56 routes within $500 \mathrm{~m}$ radius circle around the station. It takes four hours (excluding rest time) in daytime in good weather conditions. When they felt tired, they rested. Respondents were provided a map showing the walking route. The position of destination in the street network was shown in the map but the names of places and buildings were not described. The investigator asked respondents to answer the interview when they arrived at each scheduled stop. From these questions, six legibility parameters were defined (Table 6). Items asked in the psychological experiment were:

- The ability to identify the correct traveling path

- The sense of difficulty in choosing the correct route to travel

- The ability to memorize precisely the traveled route sections: it was measured in two ways

- Ability to draw correctly the traveled route on a street network map

- Ability to identify route scenes from a set of photographs.

The survey was conducted under the following conditions. A map sheet of the street network was shown to the subjects for 15 seconds. Subjects were asked to travel the route by recalling the map. If the subject could not remember the correct route and selected an incorrect route in an intersection, the correct route was shown by the instructor.

\section{(6) Analysis of six types of perceived legibility pa- rameters and creation of prediction model of the legibility}

The mean of six legibility parameters was computed using about seven types of routes given by the cluster analysis. The difference of the mean was tested by ANOVA.

In order to predict legibility of the route, a multiple regression analysis was carried out with the PCA re- 
Table 3 Results of principal component analysis.

\begin{tabular}{|c|c|c|c|c|}
\hline $\begin{array}{l}\text { Physicat } \\
\text { Parameter } \\
\text { component }\end{array}$ & $\begin{array}{l}\text { Angular direc- } \\
\text { tion change }\end{array}$ & $\begin{array}{l}\text { Amount of } \\
\text { street visibility }\end{array}$ & $\begin{array}{l}\text { Width varia- } \\
\text { bility }\end{array}$ & $\begin{array}{l}\text { Axis deviation } \\
\text { (Straightness) }\end{array}$ \\
\hline The average rotation angle in a route & 0.811 & -0.272 & -0.355 & -0.166 \\
\hline $\begin{array}{l}\text { The average angle between route segments and } \\
\text { the linear axis drawn from each route intersec- } \\
\text { tion to the destination of the route }\end{array}$ & 0.755 & -0.480 & 0.0261 & 0.031 \\
\hline $\begin{array}{l}\text { The average change in the linear axis angles } \\
\text { drawn from each route intersection to the des- } \\
\text { tination of the route. }\end{array}$ & 0.650 & 0.472 & -0.238 & 0.186 \\
\hline $\begin{array}{l}\text { The available visual information amount of a } \\
\text { route }\end{array}$ & 0.487 & 0.758 & 0.1289 & 0.092 \\
\hline The average path width in a route & 0.188 & 0.454 & 0.7562 & -0.133 \\
\hline Changes in width of a route & 0.286 & -0.417 & 0.5504 & -0.473 \\
\hline $\begin{array}{l}\text { The average area between route and the linear } \\
\text { axis }\end{array}$ & 0.138 & -0.423 & 0.4340 & 0.768 \\
\hline Cumulative percentage & 28.915 & 52.639 & 70.678 & 83.584 \\
\hline Contribution percentage of parameters & 28.915 & 23.724 & 18.040 & 12.906 \\
\hline
\end{tabular}

sults and physical route configuration parameters. The four components of the PCA, such as angular direction change, available visual information amount, width variability, and axis deviation change were used as independent variables while six legibility scales from the on-site experimental data were used as dependent variables in the multiple regression analysis (Table 6).

\section{RESULTS AND DISCUSSION}

\section{(1) Principal component analysis}

Principal Component Analysis was accomplished for the hypothetical parameters explained in the method section. The parameters were collected from 231 route segments in the study area. Table 3 gives the results of the PCA

According to the PCA results, the essential and more independent attributes of the routes could be identified. Regarding the streets around the Minami Urawa station, four types of principal components were achieved:

Component 1: Based on the angular direction change on the route

Component 2: Based on the amount of street visibility around the route

Component 3: Based on the width variability of the route

Component 4: Based on the axis deviation (straightness) of the route

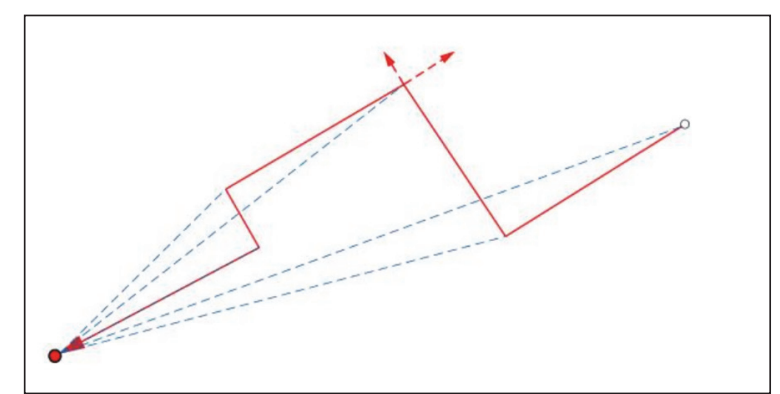

Fig. 4 Angle and traveling direction from the origin to each Intersection.

(1) Component 01: The Angular Direction Change

This route type was categorized based on the angle between the route segment and the linear axis from the origin to each route intersection (Fig. 4). represents an example sketch of this type of route.

(2) Component 02: The amount of street visibility

This component was based on the amount of available visual information on only one parameter, that is, the average visible area, which contributed independently to this component. If the amount of street visibility was larger, such routes had a higher legibility. It should be noted that the visibility effect was just a simple and indirect effect hidden under the geometric configuration of route segment. Yet, this effect was rather independent of other configuration parameters. It implied that the visibility in the route design should be considered and enhanced to improve legibility. The available visual information amount for different routes were different (Fig. 5). 


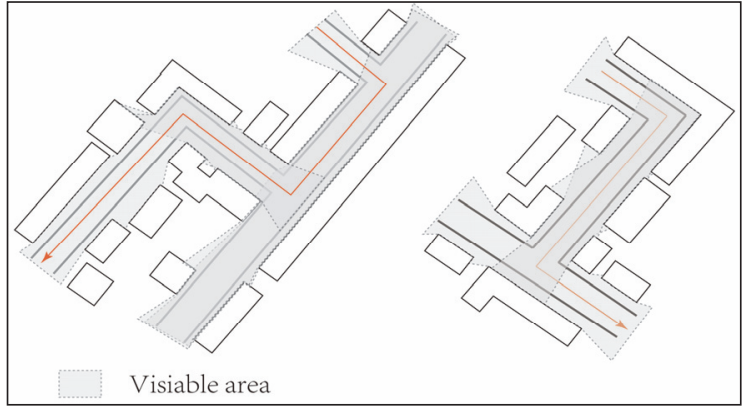

Fig. 5 The effect of the available visual information amount around the route.

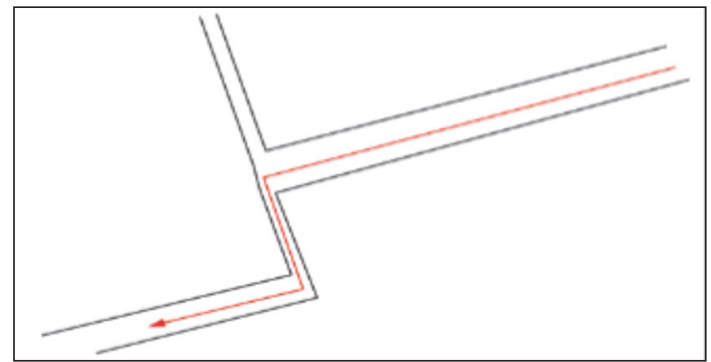

Fig. 6 The route width fluctuation.

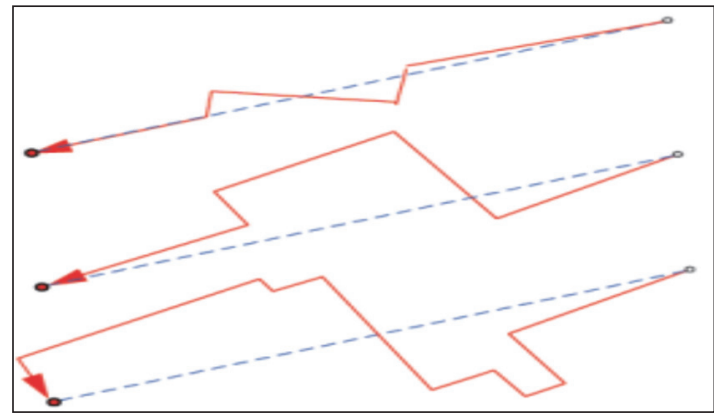

Fig. 7 The different degrees of route straightness.

(3) Component 03: The Width Variability

Based on the changes in the route width, PCA classified the types of routes. When the traveling route has frequent fluctuations in the route width, the ability to memorize the route will become low. Accordingly, such routes could be categorized under the minimum legibility category in the study area. Fig. 6 illustrates this route category.

\section{(4) Component 04: Axis Deviation}

If the deviation between the route and the linear axis of the route is lower, subsequently the route is nearly straight. In that case the traveler could easily view the origin and destination points of his route. Fig. 7 exhibits some example sketches for these route types.

\section{(2) Cluster analysis}

At this juncture, the four scores of components for PCA route samples were analyzed by cluster analysis. The analysis produced seven types of routes in the study area. The description of each route type in
Table 4 was derived by comparing the average score of four principal components with each route type sample.

The shortest routes to all nodes in the street network from each East and West exits of the Minami Urawa Station to different destinations were classified into these seven route types and they were manifested in the map (Fig. 8). The mark of each route type is displayed on the destination intersection (origin is the railway station) within 500 m radius circle of the study area. Distribution of the seven route types around the station seemed to match with the characteristic of the street network. Routes near Station (D), and Station square type (F) were observed on both sides of the station. The main road around Station (A) located mainly on the South- West side and was limited to the center road on the North- East side. Low field of view (E) and high intersection type (G) were strongly noted on the East side of the station.

Based on the regression analysis, the angular direction change, available visual information amount, and width variability were contributing factors to legibility. Thus, it was assumed that route types A, B, C, $\mathrm{D}, \mathrm{F}$, which had attributes of small angular variation in direction, large amount of street visibility and large width variability were relatively legible routes compared with other route types. The surrounding area of Minami-Urawa Station was divided into four districts by the Musashino Line and Keihintohoku Line. Table 5 shows the proportion of route types within four districts. The proportions of routes in the South-West district are as follows: A (22\%), B (25\%), C (12\%), $\mathrm{D}(7 \%)$, and $\mathrm{F}(5 \%)$. In addition, the route types $\mathrm{E}$ and $G$ are negative on legibility. The proportions of these types in the South-West district are E (29\%), and $\mathrm{G}(0 \%)$. In the same way, the North-West district has similar attributes with the South-West district. Therefore, the South-West and the North-West districts can be legible street networks.

\section{(3) On-site psychological experiments on route legibility}

The result of perceived legibility parameters is shown in Table 6. In this table, two parameters, namely cognitive gaps in identifying the direction of the destination and the difficulty of the route choice in intersections were the negative parameters and when these values were low, the route was legible. The station square type (F) got the highest score on these parameters without negative result and could be steadily legible route type. The straight routes (C) also got higher scores on angular direction change and axis deviation. Low field of view (E) and High intersections (G) were considered as less legible route types. 

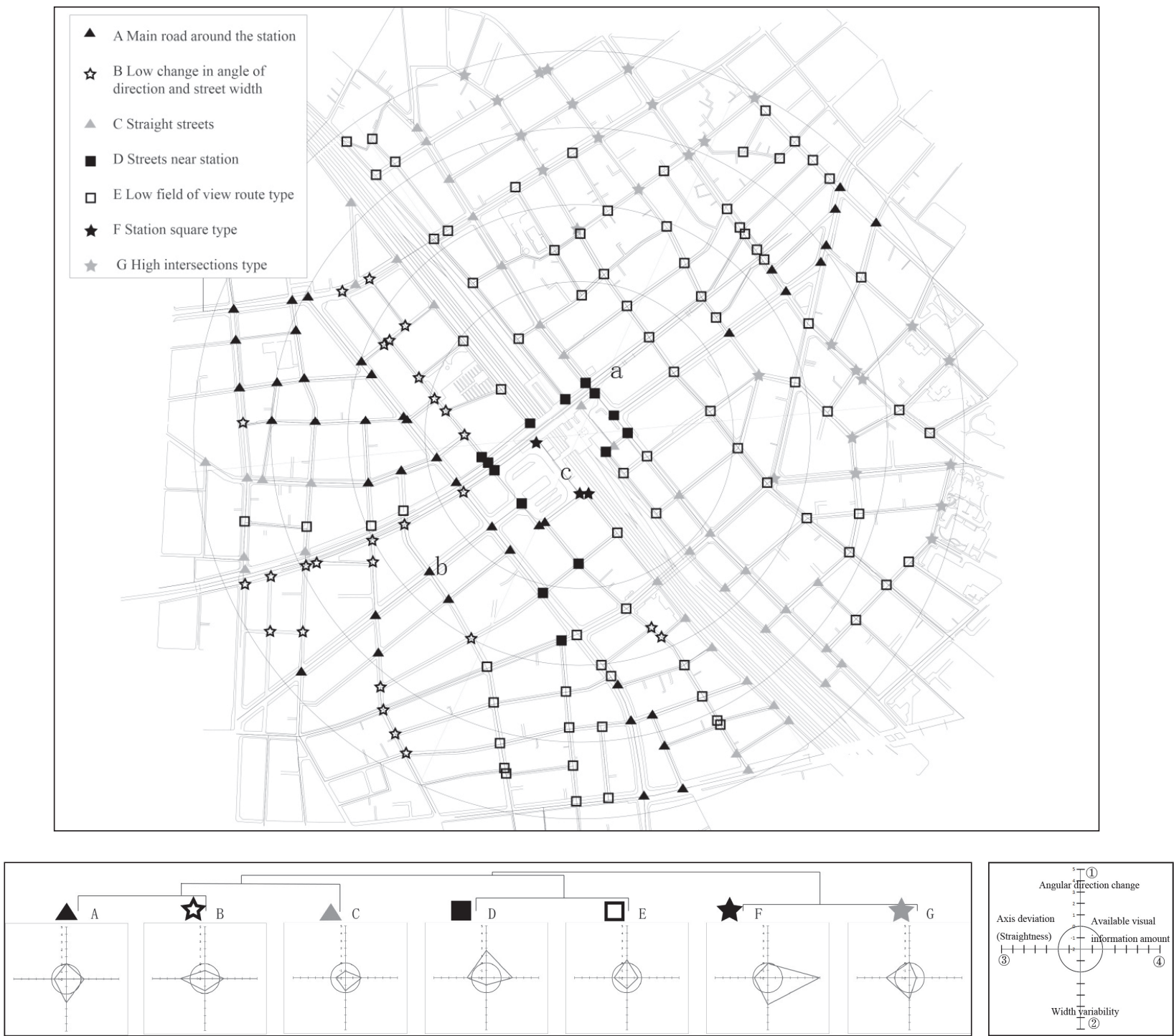

Fig. 8 Classification of route intersections into seven route types.

Table 4 Seven route types classified in the cluster analysis.

\begin{tabular}{|c|l|}
\hline $\begin{array}{c}\text { Route type } \\
\text { A Main road } \\
\text { around the station }\end{array}$ & $\begin{array}{l}\text { Description } \\
\text { Route width is wide and the width becomes wider on the intersections among the routes. } \\
\text { Streetscape visibility is high, making it easy for travelers to acquire much visual infor- } \\
\text { mation. From station to destination, the route is basically straight with few intersections. } \\
\text { Route type A is legible in the study area. }\end{array}$ \\
$\begin{array}{c}\text { B Low change } \\
\text { tion angle of direc- } \\
\text { width the route }\end{array}$ & $\begin{array}{l}\text { Higher number of intersections could be seen. Route width does not change frequently and } \\
\text { basically, narrow routes continue. However, the traveling route and the linear axis of the } \\
\text { route are compatible. Street space visibility is high and the route has a good outlook. }\end{array}$ \\
\hline C Straight & $\begin{array}{l}\text { The route is basically straight from the start to the end. The deviation between the route } \\
\text { and the linear axis is lower. }\end{array}$ \\
station Streets near & $\begin{array}{l}\text { Available visual information around the route is high. Large number of intersections can } \\
\text { be seen. There is a large angle between the route and the linear axis. And, the route tends } \\
\text { to be narrow obviously. }\end{array}$ \\
\hline E Low field of & $\begin{array}{l}\text { Slightly larger gap between route and the linear axis of the route. Visual information } \\
\text { amount around the route is slightly less. Number of occasions that the route width changes } \\
\text { from wide to narrow is high. Thus, the legibility of the route is lower. }\end{array}$ \\
\hline F route type & $\begin{array}{l}\text { The highest amount of visual information is available to the travelers. Route width is wider. } \\
\text { This type could be seen only at the station square in the study area. }\end{array}$ \\
\hline square type & $\begin{array}{l}\text { Route width changes frequently. The number of intersections is also high. The deviation } \\
\text { between the route and the linear axis of the route is larger. This route type is not legible. }\end{array}$ \\
\hline sections type
\end{tabular}


Table 5 The distribution of various types in different areas.

\begin{tabular}{|c|c|c|c|c|c|c|c|c|}
\hline Trea & $\mathrm{A}$ & $\mathrm{B}$ & $\mathrm{C}$ & $\mathrm{D}$ & $\mathrm{E}$ & $\mathrm{F}$ & $\mathrm{G}$ & Total \\
\hline South-East & $12 \%$ & $0 \%$ & $23 \%$ & $7 \%$ & $38 \%$ & $0 \%$ & $20 \%$ & $100 \%$ \\
\hline South-West & $22 \%$ & $25 \%$ & $12 \%$ & $7 \%$ & $29 \%$ & $5 \%$ & $0 \%$ & $100 \%$ \\
\hline North-East & $2 \%$ & $0 \%$ & $13 \%$ & $4 \%$ & $56 \%$ & $0 \%$ & $25 \%$ & $100 \%$ \\
\hline North-West & $39 \%$ & $20 \%$ & $23 \%$ & $6 \%$ & $12 \%$ & $0 \%$ & $0 \%$ & $100 \%$ \\
\hline
\end{tabular}

Table 6 Legibility parameters measured on-site.

\begin{tabular}{|c|c|c|}
\hline $\begin{array}{l}\text { Legibility } \mathrm{Pa}- \\
\text { rameter }\end{array}$ & Measurement method & Description \\
\hline $\begin{array}{l}\text { Cognitive } \\
\text { gaps in identi- } \\
\text { fying the di- } \\
\text { rection of the } \\
\text { destination }\end{array}$ & $\begin{array}{l}\text { It is the difference between the actual } \\
\text { direction and the perceived direction, } \\
\text { from the subject's interviewed position. } \\
\text { The average value observed in each in- } \\
\text { tersection was taken for one route. (an- } \\
\text { gle) }\end{array}$ & $\begin{array}{l}\text { Understanding the direction of the destination is im- } \\
\text { portant to travel correctly. If the subject predicts dire- } \\
\text { tion incorrectly, it tells that the lucidity of the route is } \\
\text { low. }\end{array}$ \\
\hline $\begin{array}{l}\text { Recall rate of } \\
\text { the memo- } \\
\text { rized route } \\
\text { scenes }\end{array}$ & $\begin{array}{l}\text { Number of photos correctly recognized } \\
\text { / Total number of the correct photos of } \\
\text { route space. }(\%)\end{array}$ & $\begin{array}{l}\text { It is assumed if the route space is highly memorized; } \\
\text { the route has a good legibility. The memory of the } \\
\text { route space is one of the components on the route } \\
\text { knowledge. }\end{array}$ \\
\hline $\begin{array}{l}\text { Difficulty of } \\
\text { the route } \\
\text { choice in in- } \\
\text { tersections }\end{array}$ & $\begin{array}{l}\text { A scale was used to analyze this pa- } \\
\text { rameter. Five points Likert scale repre- } \\
\text { sents low to high hesitation in finding } \\
\text { the correct route in each street junction. } \\
\text { (1 } \sim 5 \text { ciass,low } \sim \text { high })\end{array}$ & $\begin{array}{l}\text { When subject travels from start to end, he meets } \\
\text { many intersections of the route. The scale measures } \\
\text { the level of hesitation to choose the correct path by the } \\
\text { subject at each intersection. }\end{array}$ \\
\hline $\begin{array}{l}\text { The prefer- } \\
\text { ence for cor- } \\
\text { rect route }\end{array}$ & $\begin{array}{l}\text { Five point Likert scale was used to } \\
\text { measure the preference to select each of } \\
\text { possible route segments at intersection. } \\
\text { Only the score of correct route segment } \\
\text { was used as legibility parameter. } \\
\text { ( } 1 \sim 5 \text { ciass,low high) }\end{array}$ & $\begin{array}{l}\text { If the average scale of all intersections is higher, it } \\
\text { shows that the route has higher legibility. }\end{array}$ \\
\hline $\begin{array}{l}\text { Relative pref- } \\
\text { erence to se- } \\
\text { lect the correct } \\
\text { route segment } \\
\text { at intersection, }\end{array}$ & $\begin{array}{l}\text { This is a similar parameter with } \\
\text { abovementioned parameter. The score } \\
\text { was divided by the total of preference } \\
\text { scores to select each route segment. The } \\
\text { primacy to select a particular route seg- } \\
\text { ment compared to other segments is } \\
\text { considered by this adjustment. }(\%)\end{array}$ & $\begin{array}{l}\text { If the average scale of all intersections is higher, it } \\
\text { shows that the route has higher legibility. }\end{array}$ \\
\hline $\begin{array}{l}\text { The recogni- } \\
\text { tion rate of } \\
\text { route choice } \\
\text { on the map }\end{array}$ & $\begin{array}{l}\text { It is the percentage of correct routes } \\
\text { drawn on a map by the subjects. }(\%)\end{array}$ & $\begin{array}{l}\text { After traveling on the routes, subject was asked to } \\
\text { highlight the route he took on a street network map. } \\
\text { To highlight the traveled route accurately, recognition } \\
\text { ability using the cognitive map is required. This pa- } \\
\text { rameter also explains the clarity of the route. Different } \\
\text { from the memory of street space, this recognition can } \\
\text { be supported more by the survey knowledge rather } \\
\text { than route knowledge. }\end{array}$ \\
\hline
\end{tabular}

\section{(4) Multiple regression analysis of perceived legi- bility}

According to the results of multiple regression analysis for the legibility parameters (Tables 7, Tables 8), mainly one principal component, namely the cognitive gaps in identifying the direction of the destination, was the major visual information available. The legibility parameter of recall rate of memorized street scene is mainly influenced by principal components such as the amount of street visibility, the angular direction change and the axis deviation. Although the visual information amount contributed positively (standardized beta $=-0.383$ ), the angular direction change showed the most negative contribution (beta $=-0.538$ ).

Direction change influenced the various changes in 
Table 7 The results of multiple regression analysis.

\begin{tabular}{|c|c|c|c|c|c|}
\hline $\begin{array}{l}\text { Legibil- } \\
\text { ity } \mathrm{Pa}- \\
\text { rameter }\end{array}$ & $\begin{array}{l}\text { Multiple regression } \\
\text { equation }\end{array}$ & $\begin{array}{l}\text { Multi- } \\
\text { ple cor- } \\
\text { rela- } \\
\text { tion co- } \\
\text { effi- } \\
\text { cient }\end{array}$ & $\begin{array}{l}\text { Coeffi- } \\
\text { cient of } \\
\text { deter- } \\
\text { mina- } \\
\text { tion }\end{array}$ & $\begin{array}{l}\text { Judgment } \\
(1 \% \text { sig- } \\
\text { nificance } \\
\text { and } 5 \% \\
\text { signifi- } \\
\text { cance) }\end{array}$ & Description \\
\hline $\begin{array}{l}\text { Cogni- } \\
\text { tive gaps } \\
\text { in iden- } \\
\text { tifying } \\
\text { the di- } \\
\text { rection } \\
\text { of the } \\
\text { destina- } \\
\text { tion }\end{array}$ & $\begin{array}{l}\text { 14.667-0.806 } \times \text { an- } \\
\text { gular direction } \\
\text { change }-3.464 \times \\
\text { amount of street visi- } \\
\text { bility }-0.289 \times \text { width } \\
\text { variability }-2.253 \times \\
\text { axis deviation }\end{array}$ & 0.605 & 0.366 & $*$ & $\begin{array}{l}\text { The PCA component based on available visual } \\
\text { information, illustrated } 5 \% \text { level significance in } \\
\text { p value and the PCA component based on axis } \\
\text { deviation, showed } 1 \% \text { level significance. The } \\
\text { PCA components based on axis deviation and } \\
\text { width variability were not significant. Thus, } \\
\text { axis deviation and width variation had little in- } \\
\text { fluence in identifying the destination correctly. } \\
\text { When the partial regression coefficient of the } \\
\text { amount of street visibility and angular direction } \\
\text { change were negative, the lower the available } \\
\text { visual information and axis deviation is, the } \\
\text { worse the cognitive gaps in identifying the di- } \\
\text { rection of the destination becomes. Axis devia- } \\
\text { tion is the area size delineated by two lines of } \\
\text { the traveling route and the linear axis. When the } \\
\text { area size gets smaller, the "cognitive gaps in } \\
\text { identifying the direction of the destination" is } \\
\text { greater. The following figure of route (a) has } \\
\text { less axis deviation. Thus, route (a) allows one } \\
\text { to change walking directions many times, } \\
\text { which could cause him to lose cognitive direc- } \\
\text { tion. On the other hand, route (b) has greater } \\
\text { axis deviation but it reduces change in walking } \\
\text { direction. In this situation, pedestrians can have } \\
\text { better recognition of the route. }\end{array}$ \\
\hline & & & & & (b) \\
\hline $\begin{array}{l}\text { Recall } \\
\text { rate of } \\
\text { memo- } \\
\text { rized } \\
\text { street } \\
\text { scene }\end{array}$ & $\begin{array}{l}0.599-0.070 \times \text { angu- } \\
\text { lar direction change }- \\
0.056 \times \text { amount of } \\
\text { street visibility - } \\
0.017 \times \text { width varia- } \\
\text { bility }-0.046 \times \text { axis } \\
\text { deviation }\end{array}$ & 0.795 & 0.633 & $*$ & $\begin{array}{l}\text { According to the P- value, PCA components } \\
\text { such as angular direction change, the amount of } \\
\text { street visibility, and axis deviation illustrated } \\
5 \% \text { significance level; however, the PCA com- } \\
\text { ponent width variability was not significant at } \\
5 \% \text { level. Consequently, width variability did } \\
\text { not affect the response rate to pictures of the } \\
\text { route. }\end{array}$ \\
\hline $\begin{array}{l}\text { Diffi- } \\
\text { culty of } \\
\text { the route } \\
\text { choice } \\
\text { in inter- } \\
\text { sections }\end{array}$ & $\begin{array}{l}1.805+0.090 \times \text { angu- } \\
\text { lar direction change } \\
-0.134 \times \text { amount of } \\
\text { street visibility }+ \\
0.137 \times \text { width varia- } \\
\text { bility }+0.136 \times \text { axis } \\
\text { deviation }\end{array}$ & 0.739 & 0.545 & $*$ & $\begin{array}{l}\text { According to the P- value of each of the explan- } \\
\text { atory variables, all four PCA components dis- } \\
\text { played 5\% significance level. According to the } \\
\text { partial regression coefficient, if the availability } \\
\text { of visual information amount in one route was } \\
\text { negative or lower, the difficulty of this route } \\
\text { choice in intersections would be higher. Fur- } \\
\text { ther, if angular direction changed, width varia- } \\
\text { bility and axis deviation were positive or were } \\
\text { at higher values, thus the difficulty of selecting } \\
\text { a route at an intersection became higher. }\end{array}$ \\
\hline
\end{tabular}


Table 8 The results of multiple regression analysis.

\begin{tabular}{|c|c|c|c|c|c|}
\hline $\begin{array}{l}\text { Legibil- } \\
\text { ity } \mathrm{Pa}- \\
\text { rameter }\end{array}$ & $\begin{array}{l}\text { Multiple regres- } \\
\text { sion equation }\end{array}$ & $\begin{array}{l}\text { Multiple cor- } \\
\text { relation co- } \\
\text { efficient }\end{array}$ & $\begin{array}{l}\text { Coeffi- } \\
\text { cient of } \\
\text { deter- } \\
\text { mina- } \\
\text { tion }\end{array}$ & $\begin{array}{l}\text { Judg- } \\
\text { ment (1\% } \\
\text { signifi- } \\
\text { cance } \\
\text { and 5\% } \\
\text { signifi- } \\
\text { cance) }\end{array}$ & Description \\
\hline $\begin{array}{l}\text { The pref- } \\
\text { erence } \\
\text { for cor- } \\
\text { rect route }\end{array}$ & $\begin{array}{l}4.003-0.129 \times \text { an- } \\
\text { gular direction } \\
\text { change }+0.082 \times \\
\text { amount of street } \\
\text { visibility } \quad+ \\
0.055 \times \text { width vari- } \\
\text { ability } \\
0.086 \times \text { axis devia- } \\
\text { tion }\end{array}$ & 0.553 & 0.306 & $*$ & $\begin{array}{l}\text { Based on the } \mathrm{p}-\text { value, the PCA component, } \\
\text { namely angular direction change displayed } \\
1 \% \text { level of significance. Other PCA compo- } \\
\text { nents such as the amount of street visibility, } \\
\text { width variability, and axis deviation did not } \\
\text { show any significant influence on the prefer- } \\
\text { ence for correct route intersections. Further, } \\
\text { when the partial regression coefficient of an- } \\
\text { gular direction change was negative or lower, } \\
\text { the preference for the correct route at street } \\
\text { intersections became higher. }\end{array}$ \\
\hline $\begin{array}{l}\text { Relative } \\
\text { prefer- } \\
\text { ence to } \\
\text { select the } \\
\text { correct } \\
\text { route } \\
\text { segment } \\
\text { at inter- } \\
\text { section }\end{array}$ & $\begin{array}{l}\text { 0.625- } \\
0.024 \times \text { angular di- } \\
\text { rection change } \\
+0.027 \times \text { amount of } \\
\text { street visibility- } \\
0.014 \times \text { width vari- } \\
\text { ability- } 0.025 \times \text { axis } \\
\text { deviation }\end{array}$ & 0.474 & 0.225 & $* *$ & $\begin{array}{l}\text { Based on the P- value, the PCA component } \\
\text { of the amount of street visibility was at } 1 \% \\
\text { level of significance. PCA components such } \\
\text { as angular direction change, width variability } \\
\text { or axis deviation did not show any signifi- } \\
\text { cance in p-values. When the partial regres- } \\
\text { sion coefficient of amount of street visibility } \\
\text { was positive or higher, relative preference to } \\
\text { select the correct route segment at intersec- } \\
\text { tion became higher. }\end{array}$ \\
\hline $\begin{array}{l}\text { The } \\
\text { recogni- } \\
\text { tion rate } \\
\text { of route } \\
\text { choice on } \\
\text { the map }\end{array}$ & $\begin{array}{l}\text { 0.768- } \\
0.019 \times \text { angular di- } \\
\text { rection change }+ \\
0.050 \times \text { amount of } \\
\text { street visibility - } \\
0.015 \times \text { width vari- } \\
\text { ability - } \\
0.041 \times \text { axis devia- } \\
\text { tion }\end{array}$ & 0.701 & 0.492 & $*$ & $\begin{array}{l}\text { Based on the P- value, PCA components } \\
\text { such as the amount of street visibility and the } \\
\text { axis deviation were at 5\% level of signifi- } \\
\text { cance. When the partial regression coeffi- } \\
\text { cient of the PCA component, namely the axis } \\
\text { deviation, was negative or lower, the } \\
\text { memory of the correct route became higher. } \\
\text { Further, when the amount of street visibility } \\
\text { was positive or higher, the memory of correct } \\
\text { route became higher. }\end{array}$ \\
\hline
\end{tabular}

streetscape and it provided visual complexity in walking experience. The parameter, namely difficulty in the route choice in intersections depended on all four principal components. The highest contribution was observed in the route width change (beta $=0.479$ ); it implied that the road width change was a significant cue to compare the spatial feature of route segments and the rapid change in width caused hesitation to select the route segment. Overlooking various visual elements was also important in selecting route (beta of visual information amount was 0.437). The legibility parameter, preference to select the correct route segment at intersection depended on the angular direction change and the axis deviation principal components. Moreover a similar parameter, the relative preference to select the correct route segment at intersection was contributed by the amount of street visibility, the route width change, and the axis deviation. R squared for the two similar models were significant but lower than those of the other models. The preference of route segment were related not only to route configuration factors but also to other factors such as feeling of safety. These were rather independent of street legibility parameters. The legibility parameter, namely the recognition rate of route choice on the map depended on three principal components except the route width change. The highest contribution was obtained for principal component, visual information amount (beta $=0.554$ ). Five of the six legibility models significantly contributed to visual information amount. This result sufficiently supported our hypothesis on visibility contribution. On the other hand, the effect of the route width change was observed only in two models. 
Last but not least, the PCA components, namely the amount of street visibility and the angular direction change have a great influence on the legibility of the street space.

\section{CONCLUSION}

The main purpose of this research was to show the physical classification of street legibility by considering the perceived legibility by street walkers. An objective analysis of street network configuration was carried out using PCA and cluster analysis. Subjective approach was used for the questionnaire in the on-site walking experiment.

Preliminary field visits and literature survey gave us various candidates for the effective spatial parameter on legibility. As many of these candidates seemed to have interrelation and so many detailed parameters could not be manipulated for practical usage, such as legibility prediction, PCA was applied and four components were successfully obtained. These were axis variability of streets, available visual information on streets, width variability of streets, and the axis deviation of streets.

The results of PCA were further classified using cluster analysis and seven route types were obtained. By specifying the type of route concerned, the legibility characteristics were easily understood and it was possible to propose an appropriate street design to enhance the spatial legibility. However, it should be noted that our results are not about a particular route segment, but about possible routes pedestrians take. This means that one and the same part of the route segment can be rated as legible or not legible depending on which route the segment belongs. In the subjective approach towards perceived legibility, six psychological parameters were measured in the questionnaire. By referring to past research on the spatial knowledge level, wayfinding, and cognitive map, we have taken a conventional concept that legibility is a complex cognitive process supported by multi-dimensional parameters. The six parameters used in this study were among the candidates for perceived legibility. Based on this idea, specifying the most legible route is very difficult without judging the primacy of one of the legibility aspects. Yet, we demonstrated that the component of visual information amount significantly and commonly contributed to five legibility regression models. It should be considered in the street improvement project. If we look at the multiple scores of the legibility of the seven route types, route type $\mathrm{F}$, or the station square type, was the best route type with high legibility. The second best route type was C, which largely comprised of straight routes. The lowest legibility was shown by the route types with low amount of visual information and large number of intersections, namely types $\mathrm{E}$ and $\mathrm{G}$.

This study focused basically on the shortest path from origin to destination. The future research will cover the routes other than the shortest paths. A geographical information system will also enable us to assess the comprehensive legibility of street network at the district level by integrating all the potentials of each route section selected as part of the pedestrian route.

\section{REFERENCES}

1) Kozlowski, L. T. and Bryant, K. J.: Sense of direction, spatial orientation, and cognitive maps, Journal of Experimental Psychology: Human Perception and Performance, Vol. 3, No. 4, pp. 590-598, 1977.

2) Sholl, J. M., Acacio, J. C., Makar, R. O. and Leon, C.: The relation of sex and sense of direction to spatial orientation in an unfamiliar environment, Journal of Environmental Psychology, Vol. 20, pp. 17-28, 2000.

3) Golledge, R. G.: Human wayfinding and cognitive maps, In: Wayfinding Behaviour: Cognitive Mapping and Other Spatial Processes, pp. 5-45, Baltimore: Johns Hopkins University Press, 1999.

4) Zhou, J. and Golledge, R.: A GPS-based analysis of household travel behavior, Paper presented to Western Regional Science Association, Hawaii: Kauai, 2000.

5) Weisman, J.: Evaluation of architectural legibility: Wayfinding in the built environment, Environment and Behavior, Vol. 13, pp. 189-204, 1981.

6) Raubal, M.: Agent-based simulation of human wayfinding: A perceptual model for unfamiliar buildings, Vienna University of Technology, 2001.

7) Sandstrom, N. J., Kaufman, J. and Huettel, A. S.: Males and females use different distal cues in a virtual environment navigation task, Cognitive Brain Research, Vol. 6, No. 4, pp. 351-360, 1998.

8) Sorrows, M. E. and Hirtle, S. C.: The nature of landmarks for real and electronic spaces, In: C. Freksaand and D. M. Mark (Eds.), Spatial Information Theory, Lecture Notes in Computer Science, Vol. 1661, pp. 37-50, Berlin: Springer, 1999.

9) Lynch, K.: The Image of the City, Cambridge: MIT Press, 1960.

10) Raubal, M. and Winter, S.: Enriching wayfinding instructions with local landmarks, In: M. Egenhofer and D. Mark (Eds.), Geographic Information Science - Second International Conference, GIScience 2002, Boulder, CO, USA, September 2002. Lecture Notes in Computer Science, 2478, pp. 243-259, Springer, Berlin, 2002.

11) Saaty, T. L.: The Analytic Hierarchy Process, McGrawHill, New York, 1980.

12) Passini, R.: Spatial representations, a wayfinding perspective, Journal of Environmental Psychology, Vol. 4, pp. 153164, 1984.

13) Başkaya, A., Wilson, C. S. and Özcan, Y. Z.: Wayfinding in an unfamiliar environment: Different spatial settings of two polyclinics, Environment and Behavior, Vol. 36, pp. 839867, 2004.

14) Winter, S. and Raubal, M. and Nothegger, C.: Focalizing measures of salience for route directions, In: Meng, L., Zipf, A., Reichenbacher, T. (Eds.), Map-Based Mobile Services - Theories, Methods and Design Implementations, Springer Geosciences, Berlin, pp. 127-142, 2005.

15) Omer, I. and Goldblatt, R.: The implications of inter-visi- 
bility between landmarks on wayfinding performance: An investigation using a virtual urban environment, Computers, Environment and Urban Systems, Vol. 31, pp. 520-534, 2007.

16) Abu-Obeid, N.: Abstract and scenographic imagery: The effect of environmental form on wayfinding, Journal of Environmental Psychology, Vol. 18, pp. 159-173, 1998.

17) Shokouhi, M.: Legible cities: The role of visual clues and pathways configuration in legibility of cities, Proceedings 4th International Space Syntax Symposium, London, 2003.

18) Kuipers, B.: Modeling spatial knowledge, Cognitive Science, Vol. 2, pp. 129-153, 1978.

19) Turner, A. and Penn, A.: Encoding natural movement as an agent-based system: An investigation into human pedestrian behavior in the built environment, Environment and Planning B: Planning and Design, Vol. 29, pp. 473-490, 2002.

20) Taguchi, T. and Wada, N.: Streets networks and spatial domain around stations [in Japanese], Summaries of Technical Papers of Annual Meeting Architectural Institute of Japan, pp. 441-444, 1998.

21) Önde, D. E. and Gigi, Y.: Reading urban spaces by the space-syntax method: A proposal for the South Haliç Region, Cities, Vol. 27, pp. 260-271, 2010.

22) Hund, A. M. and Nazarczuk, N.: The effects of sense of direction and training experience on wayfinding efficiency, Journal of Environmental Psychology, Vol. 29, pp. 151159, 2009.

23) O’Connor, A., Zerger, A. and Itami, B.: Geo-temporal tracking and analysis of tourist movement, Mathematics and Computers in Simulation, Vol. 69, No. 1-2, pp. 135150, 2005.

24) Oh, K.: Landscape information systems: A GIS approach to mapping urban development, Landscape and Urban Planning, Vol. 54, pp. 79-89, 2001.

25) Schmitz, S.: Gender differences in acquisition of environmental knowledge related to wayfinding behaviour spatial anxiety and self-estimated environmental competencies, Sex Roles: A Journal of Research, Vol. 41, No. 1-2, pp. 7193, 1999.

26) Soini, K.: Exploring human dimensions of multifunctional landscapes through mapping and map-making, Landscape and Urban Planning, Vol. 57, pp. 225-239, 2001.

27) Xia, J., Arrowsmith, C., Jackson, M. and Cartwright, W.: The wayfinding process relationships between decisionmaking and landmark utility, Tourism Management, Vol. 29, pp. 445-457, 2008.

28) Arrowsmith, C., Zanon, D. and Chhetri, P.: Monitoring visitor patterns of use in natural tourist destinations, In: C. Ryan, S. Pageand and M. Aicken (Eds.), Taking Tourism to the Limits: Issues, Concepts and Managerial Perspectives, pp. 33-52, The Netherlands: Elsevier, 2005.

29) Kim, H. K. and Sohn, D. W.: An analysis of the relationship between land use density of office buildings and urban street configuration, Cities, Vol. 19, No. 6, pp. 409-418, 2002.

(Received August 6, 2015) 